\title{
Investigation on the relationship of service Quality On Tourist Satisfaction and Loyalty: Case Study of Ardabil County
}

\author{
Robab Naghizadeh*
}

Keywords: KANO Model

Tourists'satisfaction

Service Quality

Ardabil County

Article History:

Submitted:20.02.2019

Accepted:13.05.2019

\begin{abstract}
The objective of this study is to investigate tourist' satisfaction of the Ardabil County tourism Service Quality using KANO model. In this case, Ardabil County was chosen as a destination (Ardabil County covers an area $3810 \mathrm{~km} 2$ in the north west of Iran). In order to assessment of tourist satisfaction of the Ardabil County tourism Service Quality, using KANO model, Questionnaire as survey instrument, was used. The validity and reliability of the survey was based on content validity, and Cronbach's Alpha value in SPSS Version 24. In total, 384 by sampling method were distributed among tourists in the summer. Evaluation of tourist' satisfaction in KANO model also indicated the tourists from One Dimensional with satisfaction coefficient (0.731) are the most satisfaction. Also the least amount of tourists' satisfaction from Ardabil County tourism Services Quality is related to Basic needs with satisfaction coefficient (0.337). Moreover, the results signified the Ardabil County tourism Service Quality affect positively and significantly tourists'satisfaction. Furthermore, this study is presented the change in strategies investors, attendants and markers to planning for increasing the tourists satisfaction in the Ardabil County.
\end{abstract}

\section{Introduction}

The travel and tourism industry today is the world's largest and most diverse business sector. The importance of this industry directly results from the fact that it serves as a primary source for generating revenues, employment, private sector growth, and infrastructure development for many countries (Gee, 1999). Through these benefits, tourism development not only stimulates the growth of the industry, but also triggers overall economic growth (Lee \& Chang, 2008).Tourism has a prominent role in the international economy (Cengiz, 2012) accounting for $11 \%$ of global gross domestic product (GDP) and employing 200 million people (Okello \& Yerian, 2009). In the context of globalization (Mendes et al., 2010), tourism industry creates full and part-time jobs
(Vassiliadis, 2008). Consequently, the economic prominence (Cengiz, 2012) has fostered competitiveness among tourism destinations (Mendes et al., 2010).The business of tourism is complex and fragmented and since visitors arrive at the destination, until they leave, the quality of their experience is affected by many services and experiences, including a range of public and private services, community interactions, environment, and hospitality. Therefore, destinations have to deliver wonderful experiences and excellent values to visitors (WTO, 2007) to make them loyal (Haque \& Khan, 2013).

Customer satisfaction is a popular subject of research in different sectors of the economy. Satisfaction may be defined as "a judgement that

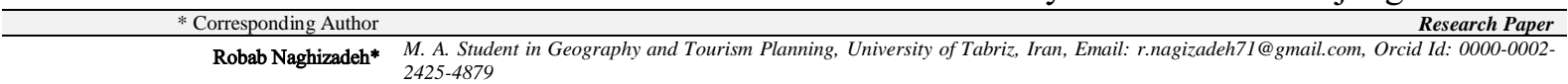


a product, or service feature, provides a pleasurable level of consumption-related fulfilment, including levels of the under or over fulfilment of a product" (Oliver, 1997: 13). However, despite many attempts to explain Customer satisfaction, a homogeneous definition does not exist, and may be influenced by the specific characteristics of each economic sector. Customer satisfaction in tourism has been described as the conformity between the expectations of the tourist and the characteristics of the host destination (Truong \& Foster, 2006: 843). Thus, customer satisfaction in tourism is determined by both subjective (i.e. customer needs and emotions) and objective factors (i.e. product and service features), however, as in the definition of customer satisfaction, a complete set of attributes that determines customer satisfaction in tourism does not exist in the literature. The analysis of customer satisfaction in tourism also reveals that the multi-dimensional construct of customer satisfaction is usually affected by other constructs (antecedents) and affects other constructs (consequences) ( Sánchez-Rebull et al, 2018:152).customer satisfaction is a psychological state. It is a sense of pleasure after customers' needs are satisfied. It's a relative relationship between customers' expectations for products or services and the actual feelings after they actually using products or sharing services (Gao \& Xue, 2016). If the number is used to measure the state of mind, this number is called customer satisfaction. Therefore, customer satisfaction is the quantification of customer satisfaction level as well as the difference function between perceived performance and expectations (or anticipation) (Wu, 2017:618). Given that a comprehensive research on the impact of service quality on the satisfaction of tourists in Iran has not been done, especially in the Ardabil province, the need for this research is felt very strongly. Therefore, the main objective of this research is to find the relationship of tourism service quality with tourist's satisfaction and loyalty to the destination (Numanoğlu and Güçer, 2018) in Ardabil city. In this regard, the hypotheses considered are as follows:
- The basic requirements of Ardabil tourism products have a direct and significant effect on the satisfaction of tourists.

- The performance requirements of tourism products in Ardabil have a direct and significant effect on the satisfaction of tourists.

- Motivational requirements of Ardabil City's tourism products have a direct and significant effect on the satisfaction of tourists.

- Satisfaction with the future behavior of tourists has a direct and equitable effect.

\section{The Study area}

Iran is one of the most spectacular countries in the world. So that the country is one of the top 10 countries in terms of attractions (cultural and civilization) tourism and one of the first five countries in the world in terms of diversity (natural environment) tourism and is one of the first three countries in the world in terms of handicrafts (Zangi Abadi et al, 2006:131). Iran has a great potential for tourism e.g. Iran is the eighteenth largest country in the world in terms of area. It is located in the southwestern Asia and covers the land area of more than $1,648,000 \mathrm{~km}^{2}$. Moreover, a review of 3167 tourist attractions found that Iran is rich in cultural and natural tourism resources; many of which are unique to the world (Zeinali et al, 2014: 68). tourism has become one of the important sectors of the global economy accounting for $11 \%$ of global gross domestic product (GDP) and employing 200 million people . In Iran, tourism is estimated to account for $5.6 \%$ of the country's total GDP, $5.1 \%$ of the country's total employments, $2.9 \%$ of the country's total capital investments, and $2.8 \%$ of the country's total exports (WTCC, 2013).

Ardabil is located in a vast plain, $45 \mathrm{~km}$ long, on the slopes of Mount Sabalan. The weather in Ardabil city is moderate and cool in the spring and summer. The handicrafts and souvenirs also include Glim, Jajim, Shal, Varni, Masnad, Pottery, Wood Industries, Leather and Carpet Artifacts and its souvenirs are honey, black halva and local sweets. Historic monuments and tourist attractions of the city include: the monument of Sheikh Safiuddin Ardabili monument related to the Ilkhani-Safavi era, the Ardabil indoor arena with 
arched vaulted ceilings, Mirza Ali Akbar mosque related to the Qajar period, the Friday mosque belonging to the Saljoughi period on the hill Historical Made, Shorabil Tourist Complex, Neur Sea Lake, $48 \mathrm{~km}$ south-east of Ardabil, warm water and Sardabeh waterfall, Shatar Gonbadi Tower in Soma Village, Sheikh Gabriel Tomb, Sheikh Safiuddin Ardabili's father in Kalkhoran neighborhood of Ardabil (Cultural Heritage, Handicrafts and Tourism Organization of Ardabil Province, 2016).

\section{Literature Review}

Bayraktaroğlu and Özgen, (2008), in a paper "Integrating the Kano model, AHP and planning matrix: QFD application in library services, In this study, QFD is applied to central library services of Dokuz Eylul University (DEU) in Izmir, Turkey. Basically, the methodology used in this study integrates the Kano model, AHP and planning matrix of house of quality. First, a focus group study is held to find out the requirements of university students for the university library that are then classified using the Kano model. The requirement categories are ranked with respect to their relative importance using analytical hierarchy process (AHP). In the last step, all findings are transferred to the planning matrix and strategies for DEU Central Library are developed. - The paper reveals marketing strategies for a nonprofit organization, a state university library, and helps the library find out its competitive position.

Mikulic and Prebezac (2016); Karakuş and Çoban (2018), studied "The Kano model in tourism research: A critical note" The study is The Kano model provides a classification of different product or service attributes (quality elements) depending on an attribute's potentials to contribute to customer dissatisfaction, on the one hand, and customer delight, on the other hand. This note addresses a severe misconception regarding the Kano model which is present in parts of the contemporary tourism literature.

Mikulić and Prebežac (2011), in a paper review of techniques for classifying quality attributes in the Kano model, to identify the theoretical/practical strengths and weaknesses of these techniques; and to provide guidance for future research and managerial practice in this area. Based on an extensive review of the literature on the Kano model and the relevant marketing/management literature, five approaches (Kano's method; "penalty-reward contrast analysis"; "importance grid"; qualitative data methods; and "direct classification") are evaluated in terms of their validity and reliability for categorising attributes in the Kano model. Several illustrative examples provide empirical evidence for the theoretical arguments advanced in the study.The Kano questionnaire and the directclassification method are the only approaches that are capable of classifying Kano attributes in the design stage of a product/service

Ponnam et al (2011), in a paper titled Satisfactionbased segmentation: Application of Kano model in Indian fast food industry, a satisfaction-based segmentation built upon Kano et al's taxonomy of product requirements, which is based in an engineering context. The proposed methodology is illustrated by segmenting young Indian consumers of fast food restaurants. CATREG procedure is used to find relevant drivers of consumer satisfaction, then, two step cluster analysis is used to derive satisfaction-based segments. A four cluster solution is obtained. After assessing the reliability and validity of segments obtained, segments are interpreted as value for money seekers, variety/novelty seekers, taste seekers and traditionalists, respectively.

Tsai et al (2011), reviewed Application of Kano Model to Discuss Tourist Demands on Service Quality in Recreational Travel. This study applied the Kano Model to discuss tourists' perceived service quality in recreational travel and to understand their actual needs, in order to provide a reference for the tourism industry to improve and enhance service quality. The results indicated that, among the 27 service quality items categorized according to the Kano Model, the Attractive quality element and Must-be element have the highest weights. The quality improvement index analysis divides service quality factors into four quadrants. Several improvement suggestions are proposed to Nanshan Cultural Tourist Area, including upgrade of transportation infrastructure, 
merchandise safety and after-sale services, personnel training, and diversity in food services.

Lin et al (2017), in a paper titled Empirical research on Kano's model and customer satisfaction, the odds of customer satisfaction were determined to identify the classification of quality attributes, and took customer psychology into account to suggest how decision-makers should prioritize the allocation of resources. A novel method for quantitatively assessing quality attributes was proposed to determine classification criteria and fit the nonlinear relationship between quality attributes and customer satisfaction. Subsequently, a case study was conducted on bicycle user satisfaction to verify the novel method. The concept of customer satisfaction odds was integrated with the value function from prospect theory to understand quality attributes. The results of this study can serve as a reference for product designers to create attractive quality attributes in their products and thus enhance customer satisfaction.

Zobnina, and Rozhkov (2018), studied Listening to the voice of the customer in the hospitality industry: Kano model application. The study is focused on tangible aspects of the hotel service product adopted from the European Hotel Guest Satisfaction Index by J.D. Power. Research methodology is based on the Kano model that enables satisfaction driver classification based on the level of their impact. Data collection was conducted via online panel representative for 1 million+ Russian cities, totaling 1,238 respondents. This paper reveals groups of customer satisfaction drivers by their impact from attractive to expected and indifferent, as well as customer preference profile by age, overall travel experience and trip purpose (recreational, sightseeing or active tourism).This paper focuses on the tangible attributes of hotel experience; the survey sample composed of Russian tourists that evaluated their satisfaction with hotels in Europe. As a result of the study, the authors test Kano model application in the hospitality and tourism industry, providing hotel managers with an advanced yet easy to use customer satisfaction measurement tool. Also, the authors demonstrate substantial differences in customer satisfaction drivers by groups that can be used to plan product development. "Expected" and "one-dimensional" groups of product features would cause customer dissatisfaction if missing and should be the first priority of management.

\section{Methodology}

In this study, Ardabil County was chosen as a tourism destination. In order to assess tourist satisfaction with tourism service quality in Ardabil County, questionnaire was used as a survey instrument. The validity and reliability of the instrument was based on content validity of Cronbach's Alpha value in SPSS software Version 24. On the whole, 384 questionnaires were distributed by sampling method among tourists in the summer in Ardabil. In order to determine which types of products and services have a greater influence on customer's satisfaction, the Kano model was applied in following steps.

Step 1, involves surveying target tourists (through questionnaires) about each theme park function through a pair of questions (functional and dysfunctional). Functional questions are asked in a positive way and dysfunctional questions are asked in a negative way. Tourists are asked to choose among five options for each question. In the case of Ardabil County, a total of 37 questions with regarding to the service quality of the Ardabil County were asked.

Step 2, is to use the evaluation table (Figure 1) to count and summarize the results. The abbreviations used in the evaluation table represent one-dimensional requirements $(\mathrm{O})$, attractive requirements (A), must-be requirements (M), indifferent requirements (I), questionable requirements $(\mathrm{Q})$ and reverse requirements $(\mathrm{R})$. For instance, if one respondent chose "I like it" for a functional question and answered "I can live with it" for a dysfunctional question, the tested product or service feature would be classified as an attractive requirement (A). For indifferent requirements (I), the customer is neither satisfied nor dissatisfied if the product, service or process is dysfunctional or fully functional with regard to that particular aspect. Questionable requirements (Q) represent results that exhibit contradictory 
Table 1 : Customer Requirements

\begin{tabular}{|c|c|c|c|c|c|}
\hline \multicolumn{6}{|l|}{ Dysfunctional } \\
\hline Customer Requirements & $\begin{array}{l}1 \\
\text { Like }\end{array}$ & $\begin{array}{l}2 \\
\text { Must-be }\end{array}$ & $\begin{array}{l}3 \\
\text { neutral }\end{array}$ & $\begin{array}{l}4 \\
\text { Live with }\end{array}$ & $\begin{array}{l}5 \\
\text { Dislike }\end{array}$ \\
\hline Like & $\mathrm{Q}$ & $\mathrm{A}$ & $\mathrm{A}$ & $\mathrm{A}$ & $\mathrm{O}$ \\
\hline Must-be & $\mathrm{R}$ & I & I & I & $\mathrm{M}$ \\
\hline Neutral & $\mathrm{R}$ & I & $\mathrm{I}$ & I & $\mathrm{M}$ \\
\hline Live with & $\mathrm{R}$ & I & I & I & $\mathrm{M}$ \\
\hline
\end{tabular}

Source: Karakuş, Y., \& Çoban, S. (2018). Evaluation of Stakeholders' Expectations Towards Congress Tourism by Kano Model: Case of Nevşehir. Anais Brasileiros de Estudos Turísticos-ABET, 8(2), 8-20: 13

answers. Reverse requirements $(\mathrm{R})$ signify that the product or service feature is not wanted by customers and that they strongly expect the reverse. One-dimensional, must-be and attractive requirements, together with indifferent requirements, are primarily what we are investigating in the Kano model analysis.

A: attractive, O: one-dimensional, M: must-be, Q: questionable result, R: reverse, and I: indifferent.

Step 3 involves determining the category of the evaluated product or service feature according to the answer frequency.

The customer satisfaction coefficient indicates that, the extent to which satisfaction increases if a product requirement is met or the extent to which satisfaction decreases if a product requirement is not met. It is useful to know that the average impact of a product or service requirement with the satisfaction of all customers. The calculation of this coefficient is represented as following as.

Enhanced Satisfaction Coefficients

$$
\begin{aligned}
& \frac{(A+0)}{(A+O+M+I)} \\
& \frac{(O+M)}{(A+O+M+I)(-1)}
\end{aligned}
$$

\section{Reduced Dissatisfaction Coefficients}

A positive customer satisfaction coefficient ranges are between zero to one. The closer value to one has the higher influence on customer satisfaction. The negative customer satisfaction operates in the same way. A value of zero signifies that this feature does not cause dissatisfaction if it is not met. In this way, all the evaluated characteristics can be represented visually in a diagram. It is helpful to know their influence on customer satisfaction and set priorities when designing products or services (Nasiri \& Amozadmahdiragi, 2014:101).

\section{Research Findings}

384 questionnaires were distributed among tourists. After collection, 360 questionnaires were used to assess and measure the opinions. In terms of gender, $55.3 \%$ of the respondents were men and $44.7 \%$ were women. In terms of age, $16.7 \%$ (a frequency of 60) were under 20 years old; $24.7 \%$ (89) between 20 and 29 years; 30.3\%(109) between 30 and 39 years; $11.9 \%$ (43) between 40 and 49 years old; $8.1 \%(29)$ between 50 and 59 years, and $8.3 \%$ (30) over 60 years of age. In terms of marital status, $41.1 \%(148)$ were single, while $58.9 \%(212)$ were married. According to the level of education, $18.9 \%(68)$ had attended primary school only; $15.3 \%(55)$ had a high school degree; 9.7\% (35) had taken some university courses; $38.6 \%$ (139) had a university degree; and finally, $17.5 \%$ (with a frequency of 63) had either a master's degree or $\mathrm{PhD}$ (Table 2). Regarding employment, we divided the studied population into several subgroups of specialists, employees, self-employed persons, workers, unemployed, collegians and students. The frequency distribution of the statistical sample according to the type of occupation in Table 2 shows that $5.6 \%(20)$ were specialists; $19.4 \%(70)$ were employees; $23.3 \%(84)$ had free occupation, those who are not government employees); $2.2 \%(8)$ 
Table 2 : Socio-demographic characteristics of tourists

\begin{tabular}{|l|l|l|l|l|l|l|l|}
\hline \multicolumn{2}{|l|}{ Gender } & \multicolumn{2}{l}{ level of education } & \multicolumn{2}{l|}{ age } & employment \\
\hline Men & $\% 55.3$ & $\begin{array}{l}\text { Primary school } \\
\text { only }\end{array}$ & $\% 18.9$ & $20>$ & $\% 16.7$ & Specialists & $\% 5.6$ \\
\hline Women & $\% 44.7$ & $\begin{array}{l}\text { high School } \\
\text { degree }\end{array}$ & $\% 15.3$ & $20-29$ & $\% 24.7$ & Employees & $\% 19.4$ \\
\hline \multicolumn{2}{|l|}{ marital status } & $\begin{array}{l}\text { university } \\
\text { Courses }\end{array}$ & $\% 9.7$ & $30-39$ & $\% 30.3$ & $\begin{array}{l}\text { free } \\
\text { occupation }\end{array}$ & \multicolumn{2}{l|}{$\% 23.3$} \\
\hline Single & $\% 41.1$ & $\begin{array}{l}\text { university } \\
\text { degree }\end{array}$ & $\% 38.6$ & $40-49$ & $\% 11.9$ & workers & $\% 2.2$ \\
\hline Married & $\% 58.9$ & $\begin{array}{l}\text { master's and } \\
\text { Ph.D. }\end{array}$ & $\% 17.5$ & $50-59$ & $\% 8.1$ & unemployed & $\% 21.4$ \\
\cline { 4 - 8 } & & $60 \leq$ & $\% 8.3$ & students & $\% 28.1$ \\
\hline
\end{tabular}

were workers, $21.4 \%(77)$ were unemployed; and $28.1 \%(101)$ were collegians and students.

The sources of information about Ardabil based on the results include TV, national and local newspapers, information received from friends, relatives, websites, networks, signs and road signposts. The polls show that sources were $27.2 \%$ (98) TV, $14.7 \%$ (53) newspapers, 34.7\% (125) through information received from friends and acquaintances, $15.3 \%$ (55) on the Internet and $8.1 \%$ (29) through the road signs from this destination. 33.3 percent (162) of people surveyed in Ardabil were there for the first time, while 45\% (120) were there for the second time, and $21.7 \%$ (78) for the third or more. According to the length of stay, respondents can be grouped into four levels:

(a) Those who did not have a night stay in the city of Ardabil; (b) Those who stayed in Ardabil for one night;

(c) Those who stayed in Ardabil 2-3 nights; and

(d) Those who stayed in Ardabil for more than 3 nights. Frequently, the fourth group has the largest share among respondents.

$52.8 \%$ (190) of the tourists used their personal cars to travel to Ardabil city. $31.1 \%$ (112) used buses, $10.3 \%$ (37) used airplanes, and 5.8\% (21) used other forms of transport. In terms of residence, $32.8 \%$ (118) stayed in hotels and hospitality; 30.8 (111) stayed with relatives and friends; $4.4 \%$ (16) in the park and camp; $8.6 \%$ (31) camped on the street; $4.2 \%$ (15) stayed in schools; $9.2 \%$ (33) stayed in leased houses, and $10 \%$ (36) resided in the Hospitality Office(Table 3).

Table 3: Tourists tour profile

\begin{tabular}{|c|c|c|c|c|c|}
\hline \multirow{4}{*}{ type of trip } & Solitary & $\% 15.8$ & \multirow{4}{*}{ Scheduling days } & 1 to 3 days & $\% 18.3$ \\
\hline & Family & $\% 56.7$ & & 4 to 6 days & $\% 35$ \\
\hline & Group (tour and friends) & $\% 16.9$ & & 7 to 10 days & $\% 23.6$ \\
\hline & Another shape & $\% 10.6$ & & More than 10 days & $\% 23.1$ \\
\hline \multirow{4}{*}{ staying time } & No overnight stay & $\% 14.4$ & \multirow{4}{*}{ Transportation } & personal car & $\% 52.8$ \\
\hline & A full day & $\% 11.7$ & & Bus & $\% 31.1$ \\
\hline & 2-3 night and day & $\% 28.3$ & & Airplane & $\% 10.3$ \\
\hline & More than 3 nights & $\% 45.6$ & & Another shape & $\% 5.8$ \\
\hline \multirow{4}{*}{$\begin{array}{l}\text { Purpose of } \\
\text { the trip }\end{array}$} & Meet relatives and friends & $\% 31.4$ & \multirow{4}{*}{ Travel costs } & Up to 400 thousand & $\% 20.3$ \\
\hline & See Historical Cultural Attractions & $\% 30$ & & Up to 800 thousand & $\% 30.3$ \\
\hline & See Natural Attractions & $\% 28.3$ & & Up to 1,200 thousand rubles & $\% 22.2$ \\
\hline & Other goals & $\% 10.3$ & & Up to 1600 tones & $\% 27.2$ \\
\hline
\end{tabular}


Table 4 : Satisfaction and dissatisfaction coefficients of basic needs

\begin{tabular}{|l|l|l|l|l|}
\hline \multirow{2}{*}{ Row } & Indicators & $\begin{array}{l}\mathrm{A}+\mathrm{O}) /( \\
\mathrm{A}+\mathrm{O}+\mathrm{M}+\mathrm{I})(\end{array}$ & $\begin{array}{l}\mathrm{O}+\mathrm{M}) /( \\
\mathrm{A}+\mathrm{O}+\mathrm{M}+\mathrm{I})(-1)(\end{array}$ & $\begin{array}{l}\mathrm{A}-\mathrm{M}) /( \\
(\mathrm{A}+\mathrm{O}+\mathrm{M}+\mathrm{I})\end{array}$ \\
\cline { 3 - 5 } & & $\begin{array}{l}\text { Satisfaction } \\
\text { factor } \\
0 \text { to } 1)(\end{array}$ & $\begin{array}{l}\text { Dissatisfaction } \\
\text { rate } \\
0 \text { to }-1)(\end{array}$ & $\begin{array}{l}\text { total } \\
\text { satisfaction }\end{array}$ \\
\hline 1 & & 0.407 & -0.657 & -0.25 \\
\hline 2 & Historical sites and ancient monuments & 0.396 & -0.698 & -0.302 \\
\hline 3 & Destination cleanliness & 0.380 & -0.640 & -0.260 \\
\hline 4 & Security & 0.360 & -0.666 & -0.306 \\
\hline 5 & Entertainment services and facilities & 0.337 & -0.641 & -0.303 \\
\hline 6 & Access and accommodation in schools and parks & 0.317 & -0.627 & -0.310 \\
\hline 7 & Accommodation facility & 0.305 & -0.671 & -0.366 \\
\hline 8 & Fraditions and customs of local customs & 0.304 & -0.648 & -0.344 \\
\hline 9 & WCs & 0.275 & -0.704 & -0.429 \\
\hline
\end{tabular}

\section{Kano Model Results}

In this research, after analyzing the questions of the Kano questionnaire according to the data of Table (4), 9 factors included: services and entertainment facilities, historical sites and ancient buildings, tradition and local customs, friendly behavior and hospitality, the hospitality of the host community, residential facilities, destination cleanliness, security, WCs, access and accommodation in schools and parks were identified as the main needs of tourists, according to the data provided in the table (5) in priority order the factor of historical sites and ancient buildings with a satisfaction index of 0/407 is the most important indicator, the purity of the destination with a satisfaction rate of 0/396 in the second stage, security with a satisfaction rate of $0 / 380$ is at the next level of satisfaction. This means that the tourists expect to receive these services. So their existence does not have a special satisfaction for the tourist, if they were not, there would be considerable discontent for the tourist.

Residential facilities with a satisfaction rating of 0.627 , the lowest index and WCs with a dissatisfaction rate of -0.1704 , in terms of creating a first-rate dissatisfaction from visiting tourists from Ardabil tourism places. Also, in relation to overall satisfaction of basic needs, based on each

Table 5 : Satisfaction and dissatisfaction coefficients of motivational needs

\begin{tabular}{|c|c|c|c|c|}
\hline \multirow[t]{2}{*}{ Row } & \multirow[t]{2}{*}{ Indicators } & $\begin{array}{l}\mathrm{A}+\mathrm{O}) /( \\
\mathrm{A}+\mathrm{O}+\mathrm{M}+\mathrm{I})(\end{array}$ & $\begin{array}{l}\mathrm{M}+\mathrm{O}) /( \\
\mathrm{A}+\mathrm{O}+\mathrm{M}+\mathrm{I})(-1)(\end{array}$ & $\begin{array}{l}\mathrm{A}-\mathrm{M}) /( \\
\mathrm{A}+\mathrm{O}+\mathrm{M}+\mathrm{I})(\end{array}$ \\
\hline & & $\begin{array}{l}\text { Satisfaction } \\
\text { factor } \\
0) \operatorname{to}(1\end{array}$ & $\begin{array}{l}\text { Dissatisfaction rate } \\
0) \text { to(-1 }\end{array}$ & $\begin{array}{l}\text { total } \\
\text { satisfaction }\end{array}$ \\
\hline 1 & Fueling services & 0.777 & -0.486 & 0.291 \\
\hline 2 & green spaces & 0.729 & -0.451 & 0.278 \\
\hline 3 & flora and faunas, and certain natural events & 0.709 & -0.361 & 0.348 \\
\hline 4 & Tourist information centers & 0.687 & -0.401 & 0.286 \\
\hline 5 & Car assistance bases & 0.684 & -0.358 & 0.326 \\
\hline 6 & prayer places & 0.681 & -0.378 & 0.303 \\
\hline 7 & urban vitality and well-being & 0.655 & -0.404 & 0.251 \\
\hline 8 & monetary and banking services & 0.641 & -0.418 & 0.223 \\
\hline 9 & Landscapes and natural scenery & 0.640 & -0.461 & 0.179 \\
\hline 10 & Communication systems (Internet, telephone, ..) & 0.639 & -0.496 & 0.143 \\
\hline 11 & Variety of activities & 0.590 & -0.492 & 0.161 \\
\hline 12 & Bread supply in bakery and food & 0.590 & -0.524 & 0.066 \\
\hline 13 & Signs (signs, guides, tags, brochures, etc.) & 0.575 & -0.406 & 0.169 \\
\hline 14 & Red Crescent bases & 0.569 & -0.447 & 0.122 \\
\hline 15 & Nightly entertainments & 0.511 & -0.481 & 0.030 \\
\hline
\end{tabular}


of the indicators, it can be concluded that among these indicators, historical sites with values of 0.25 , security with a value of -0.260 and destination's cleanliness with a value of -0.302 in the order of priority, the degree of total satisfaction has been of primary importance, and in contrast to the healthcare provider with a value of -0.429 , tradition and local customs practices with a value of -0.366 , and behavioral and host hospitality with a value of -0.344 have a little bit of importance.

According to the results of the kano questionnaire, 15 factors including diversity of activities, flora and fauna s, and certain natural events, landscapes and natural scenery, green spaces, urban vitality and well-being, nightly entertainments, communication systems, tourist information centers, guidance signs, bakeries and food, prayer places, car assistance bases, Red Crescent bases, monetary and banking services, and fueling services were identified as the motivational needs of tourists. Based on the data in Table 6, in which 15 factors related to the motivational needs of tourists have been examined, according to the priority of the fuel service provider with the satisfaction index of 0.777 , the most important indicator, the condition of the green area with a satisfaction index of 0.729 and flora and fauna and natural events with a satisfaction of 0.709 are in the next stage of satisfaction (Table 6).

These requirements, due to their surprise, bring them a significant amount of satisfaction for the tourist, while their lack of satisfaction will be unreasonable. The car assistance bases with a disparity of -0.358 the least important indicator and the supply of bread in bakery and food products with a coefficient of -0.524 is due to the lack of satisfaction of the first place on the part of tourists. Also, according to the total satisfaction index and the priority of flora and fauna and special natural events with a value of 0.348 , the Car assistance bases with a value of 0.326 and places of prayer with a value of 0.303 had a higher degree of satisfaction. In front of the nightly entertainments with a value of 0.030 , the supply of bread in the bakery and food with a value of 0.066 and Red Crescent base with a value of 0.122 have little importance.

In order to investigate the operational needs of tourists, 11 factors include: cultural

services and facilities, mineral waters, architecture, souvenirs, arts and crafts, local food, restaurants and food preparation, traffic and crowding, hospitals and pharmacy services Cars, taxis and public cars and tourism services were studied as the operational needs of tourists (Table 6). Accordingly, the priority of taxis and public cars with a satisfaction index of 0.794 is the most

Table 6 : Satisfaction and dissatisfaction coefficients of functional requirements

\begin{tabular}{|c|c|c|c|c|}
\hline \multirow[t]{2}{*}{ Row } & \multirow[t]{2}{*}{ Indicators } & $\begin{array}{l}\mathrm{A}+\mathrm{O}) /( \\
\mathrm{A}+\mathrm{O}+\mathrm{M}+\mathrm{I})(\end{array}$ & $\begin{array}{l}\mathrm{M}+\mathrm{O}) /( \\
\mathrm{A}+\mathrm{O}+\mathrm{M}+\mathrm{I})(-1)(\end{array}$ & $\begin{array}{l}\mathrm{A}-\mathrm{M}) /( \\
\mathrm{A}+\mathrm{O}+\mathrm{M}+\mathrm{I})(\end{array}$ \\
\hline & & $\begin{array}{l}\text { Satisfaction } \\
\text { factor } \\
(0 \text { to } 1)\end{array}$ & $\begin{array}{l}\text { Dissatisfaction rate } \\
(0 \text { to }-1)\end{array}$ & total satisfaction \\
\hline 1 & taxis and public cars & 0.794 & -0.589 & 0.205 \\
\hline 2 & arts and crafts & 0.782 & -0.688 & 0.094 \\
\hline 3 & local food & 0.774 & -0.642 & 0.138 \\
\hline 4 & tourism services & 0.772 & -0.530 & 0.242 \\
\hline 5 & souvenirs & 0.767 & -0.628 & 0.139 \\
\hline 6 & cultural services and facilities & 0.756 & -0.703 & 0.053 \\
\hline 7 & traffic and crowding & 0.752 & -0.696 & 0.056 \\
\hline 8 & hospitals and pharmacy services Cars & 0.699 & -0.557 & 0.141 \\
\hline 9 & restaurants and food preparation & 0.693 & -0.615 & 0.078 \\
\hline 10 & architecture & 0.642 & -0.608 & 0.034 \\
\hline 11 & mineral waters & 0.612 & -0.441 & 0.171 \\
\hline
\end{tabular}


Table 7: Satisfaction and dissatisfaction coefficients of indifferent needs

\begin{tabular}{|c|c|c|c|c|}
\hline \multirow[t]{2}{*}{ Row } & \multirow[t]{2}{*}{ Indicators } & $\begin{array}{l}\mathrm{A}+\mathrm{O}) /( \\
\mathrm{A}+\mathrm{O}+\mathrm{M}+\mathrm{I})(\end{array}$ & $\begin{array}{l}\mathrm{M}+\mathrm{O}) /( \\
\mathrm{A}+\mathrm{O}+\mathrm{M}+\mathrm{I})(-1)(\end{array}$ & $\begin{array}{l}\mathrm{A}-\mathrm{M}) /( \\
\mathrm{A}+\mathrm{O}+\mathrm{M}+\mathrm{I})(\end{array}$ \\
\hline & & $\begin{array}{l}\text { Satisfaction factor } \\
0 \text { to } 1)(\end{array}$ & $\begin{array}{l}\text { Dissatisfaction rate } \\
(0 \text { to }-1)\end{array}$ & $\begin{array}{l}\text { total } \\
\text { satisfaction }\end{array}$ \\
\hline 1 & urban suburban & 0.355 & -0.181 & 0.174 \\
\hline 2 & $\begin{array}{l}\text { familiarity of residents with foreign } \\
\text { languages }\end{array}$ & 0.299 & -0.184 & 0.115 \\
\hline
\end{tabular}

important indicator, and arts, crafts and local food with satisfaction coefficients of 0.782 and 0.774 , respectively, are in the next level of satisfaction. So the tourist expects them to get better. In fact, there will be a lot of discontent with them. Mineral hot water with a disparity of -0.441 is the least important index and the services and cultural facilities (concert halls, cinemas, theaters, museums, galleries Henry and ...) with a coefficient of -0.703 from the point of view of creating dissatisfaction.

According to data on the total satisfaction index from functional needs, the tourist service agent with a value of 0.242 , taxis and public vehicles with a value of 0.205 and mineral hot water with a value of 0.171 are primarily important. in contrast to the architectural elements, services and cultural facilities (concert halls, cinema, theater, museums, galleries, etc.) and traffic and crowded with coefficients (0.034), (0.053) and (0.056) have been of little importance.

According to the results of the Kano questionnaire, 2 items were considered as the needs that tourists regard as indifferent: suburbs and the familiarity of inhabitants with foreign languages . according to the data of table (7), the urban suburban factor with a satisfaction factor of 0.355 and familiarity of residents with foreign languages with a satisfaction score of 0.299 have not been included in any of the group's basic, motivational and functional requirements. That is to say, it does not have any effect on the satisfaction of the tourist. In terms of overall satisfaction index, priority is given to the urban suburban factor with the value of 0.174 .

In terms of satisfaction of tourists, the estimation of their basic, functional and emotional needs from Ardabil's tourism sites in the Kano model, according to the surveyed indicators and quantitative analysis of the findings, accordingly, tourists had the most satisfaction with performance requirements with a satisfaction rate of 0.731 . Satisfaction has been declared and the least satisfaction is from meeting the basic needs, with a satisfaction rating of 0.341 . motivational requirements with a non-satisfaction rate of -0.461 the least important indicator and the basic requirements with a coefficient of -0.661 is due to the creation of first-rate dissatisfaction by tourists. Also, in the case of total satisfaction, it can be concluded that motivational needs were primarily important with a satisfaction index of 0.167 (Table $8)$.

Table 8: Coefficient of satisfaction and dissatisfaction of variables

\begin{tabular}{|l|l|l|l|l|}
\hline \multirow{2}{*}{ Row } & \multirow{2}{*}{\begin{tabular}{l} 
Indicators \\
\cline { 2 - 5 }
\end{tabular}} & $\begin{array}{l}\mathrm{A}+\mathrm{O}) /( \\
\mathrm{A}+\mathrm{O}+\mathrm{M}+\mathrm{I})(\end{array}$ & $\begin{array}{l}\mathrm{M}+\mathrm{O}) /( \\
\mathrm{A}+\mathrm{O}+\mathrm{M}+\mathrm{I})(-1)(\end{array}$ & $\begin{array}{l}\mathrm{A}-\mathrm{M}) /( \\
\mathrm{A}+\mathrm{O}+\mathrm{M}+\mathrm{I})(\end{array}$ \\
\cline { 2 - 5 } & $\begin{array}{l}\text { Satisfaction factor } \\
0 \text { to } 1(\end{array}$ & $\begin{array}{l}\text { Dissatisfaction rate } \\
0 \text { to }-1(\end{array}$ & total satisfaction \\
\hline 1 & $\begin{array}{l}\text { Functional } \\
\text { requirements }\end{array}$ & 0.731 & -0.607 & 0.124 \\
\hline 2 & $\begin{array}{l}\text { Motivational } \\
\text { Requirements }\end{array}$ & 0.628 & -0.461 & 0.167 \\
\hline 3 & Basic requirements & 0.341 & -0.661 & -0.320 \\
\hline
\end{tabular}


Table 9: Measuring the Impact of Basic Requirements on Tourism Satisfaction

\begin{tabular}{|l|l|l|l|}
\hline Variables of basic requirements & Chi-Square & Sig. & Cramer's V \\
\hline Historical sites and ancient monuments & 198.533 & 0.000 & 0.114 \\
\hline Destination cleanliness & 210.300 & 0.000 & 0.138 \\
\hline Security & 210.733 & 0.000 & 0.122 \\
\hline Entertainment services and facilities & 274.967 & 0.000 & 0.077 \\
\hline WCs & 293.800 & 0.000 & 0.146 \\
\hline Access and accommodation in schools and parks & 241.600 & 0.000 & 0.107 \\
\hline Accommodation facility & 225.767 & 0.000 & 0.125 \\
\hline Traditions and local customs & 260.500 & 0.000 & 0.148 \\
\hline Friendly behavior and hospitality of the host community & 246.767 & 0.000 & 0.098 \\
\hline
\end{tabular}

Measuring the Impact of the Basic Requirements of Ardabil Tourism Product on Tourism Satisfaction:

In order to prove the hypothesis, essential requirements have a significant effect on the satisfaction of tourists, Chi-Square test is used. This test is significant at 0.05 .

According to the results of the test (Table 9), with 99\% confidence, it can be concluded that there is a significant relationship between satisfaction of the underlying factors and overall satisfaction, thus assuming the existence of a relationship between the basic requirements and satisfaction is confirmed $(\mathrm{P}$-value $=\operatorname{sig}<0 / 05)$.

According to the results of V Cramer test (Table 9), the severity and extent of the relationship between the basic requirements and the satisfaction of tourists is weak. It can also be concluded that among the variables of the essential requirements of the service provider and entertainment facilities (theme parks, playgrounds, etc.) with a value of (0.077), friendly behavior and hospitality of the host society with the amount of (0.098), and access to and accommodation in schools and parks with a value of (0.107) were more severely weakened respectively. In contrast, the factor of tradition and local customs with a value of (0.148), WCs with a value of (0.146) and residential facilities with a value of $(0.125)$ show less severity than other variables in this relationship (Table 9).

\section{Measuring the Effect of Functional} Requirements of Tourism Product of Ardabil on Tourism Satisfaction:

Based on the results of the Chi-square test in Table (10), with 99\% confidence, the relationship between functional requirements and tourist satisfaction was confirmed (P-value $=\operatorname{sig}<0 / 05)$. If we refer to a meaningful level, we find that for all indices it is smaller than $0.05(\mathrm{P}$-value $=\mathrm{sig}=$ $0.000<0 / 05)$.

Table 10: Measuring the impact of functional requirements on the satisfaction of tourists

\begin{tabular}{|l|l|l|l|}
\hline Variable Functional Requirements & Chi-Square & Sig. & Cramer's V \\
\hline Mineral hot water & 223.867 & 0.000 & 0.056 \\
\hline Taxis and public cars & 251.200 & 0.000 & 0.065 \\
\hline art and craft & 209.933 & 0.000 & 0.068 \\
\hline local food & 259.567 & 0.000 & 0.059 \\
\hline Souvenir & 227.533 & 0.000 & 0.111 \\
\hline Traffic and bustle & 216.967 & 0.000 & 0.105 \\
\hline Services and cultural facilities & 234.333 & 0.000 & 0.072 \\
\hline Restaurants and food preparation & 132.300 & 0.000 & 0.111 \\
\hline Architecture & 186.867 & 0.000 & 0.080 \\
\hline tourism services & 147.233 & 0.000 & 0.110 \\
\hline Hospital and pharmacy services & 119.333 & 0.000 & 0.092 \\
\hline
\end{tabular}


The numerical value of this statistic for all essential variables is very low, so it can be concluded that the relationship of the intensity is low. A statistic of the V Cramer's test indicates that the mineral water agent with a value of (0.056), local foods with a value of 0.59 and taxis and public cars with a value of (0.065) are more severely weakened. Souvenirs and restaurants, food supply with a value of 0.111 , tourism services with a value of 0.110 and traffic and busy with a value of 0.105 show a low intensity of weakness (Table 10).

Measuring the Impact of Motivational Requirements of the Tourism Product of Ardabil city on Tourism Satisfaction

According to the above hypothesis, the relationship between the motivational requirements as the variable $X$ (independent) and satisfaction as the dependent variable (Y) with chi-square test was measured. According to the information provided, the assumption of a relationship with $99 \%$ confidence is confirmed. Therefore, the results of the test showed a positive and significant relationship between the motivational factors of Ardebil city and satisfaction $(\mathrm{P}$ value $=\operatorname{sig}<0 / 05)$ ). As can be seen, the results of V Kramer test show the severity of the relationship between the two variables lower (Table 11). In addition, among the indicators related to the motivational requirements, respectively, the factor of supplying bread in bakery and food with the quantity (0.078), communication systems (Internet, telephone, ..) with the amount (0.086) and automobile assistance centers with a value of 0.095 , the severity of the weakness was higher in contrast the status factor of the green area with the value (0.225), the monetary and banking services with the amount (0.221) and the places of prayer with a value $(0.216)$ with a lower degree of severity was explained (Table 11).

Table 11 : Measuring the Impact of Motivational Requirements on the Satisfaction of Tourists

\begin{tabular}{|l|l|l|l|}
\hline Variables of Motivational Requirements & Chi-Square & Sig. & Cramer's V \\
\hline The status of green areas & 337.267 & 0.000 & 0.225 \\
\hline Flora and fauna and special events & 449.167 & 0.000 & 0.155 \\
\hline Tourism Information Centers & 302.433 & 0.000 & 0.146 \\
\hline Car assistance bases & 232.533 & 0.000 & 0.095 \\
\hline Places to make prayers & 251.400 & 0.000 & 0.216 \\
\hline Fueling services & 253.100 & 0.000 & 0.151 \\
\hline The liveliness and hospitality of the city & 268.167 & 0.000 & 0.133 \\
\hline Landscapes and natural scenery & 468.900 & 0.000 & 0.112 \\
\hline Communication systems (Internet, telephone...) & 767.318 & 0.000 & 0.086 \\
\hline Variety of activities & 386.700 & 0.000 & 0.182 \\
\hline Bread supply in bakery and food & 228.000 & 0.000 & 0.078 \\
\hline Signage tips & 326.167 & 0.000 & 0.135 \\
\hline Red Crescent bases & 221.667 & 0.000 & 0.172 \\
\hline Nightly entertainments & 340.667 & 0.000 & 0.096 \\
\hline Monetary and banking services & 231.067 & 0.000 & 0.221 \\
\hline
\end{tabular}

Measuring the Impact of Motivational Requirements of the Tourism Product of Ardebil city on Tourism Satisfaction

According to the above hypothesis, the relationship between the motivational requirements as the variable $X$ (independent) and satisfaction as the dependent variable $(\mathrm{Y})$ with chi-square test was measured. According to the information provided, the assumption of a relationship with $99 \%$ confidence is confirmed. Therefore, the results of the test showed a positive and significant relationship between the motivational factors of Ardabil city and satisfaction $(\mathrm{P}$ value $=\operatorname{sig}<0 / 05)$ ). As can be seen, the results of V Kramer test show the severity of the relationship between the two variables lower (Table 12). In addition, among the indicators related to the motivational requirements, respectively, the factor of supplying bread in bakery and food with the quantity (0.078), communication systems (Internet, telephone, ..) with the amount (0.086) and automobile 
assistance centers with a value of 0.095 , the severity of the weakness was higher .in contrast the status factor of the green area with the value (0.225), the monetary and banking services with

Table 12: Measuring the Impact of Motivational Requirements on the Satisfaction of Tourists

\begin{tabular}{|l|l|l|l|}
\hline Variables of Motivational Requirements & Chi-Square & Sig. & Cramer's V \\
\hline The status of green areas & 337.267 & 0.000 & 0.225 \\
\hline Flora and fauna and special events & 449.167 & 0.000 & 0.155 \\
\hline Tourism Information Centers & 302.433 & 0.000 & 0.146 \\
\hline Car assistance bases & 232.533 & 0.000 & 0.095 \\
\hline Places to make prayers & 251.400 & 0.000 & 0.216 \\
\hline Fueling services & 253.100 & 0.000 & 0.151 \\
\hline The liveliness and hospitality of the city & 268.167 & 0.000 & 0.133 \\
\hline Landscapes and natural scenery & 468.900 & 0.000 & 0.112 \\
\hline Communication systems (Internet, telephone...) & 767.318 & 0.000 & 0.086 \\
\hline Variety of activities & 386.700 & 0.000 & 0.182 \\
\hline Bread supply in bakery and food & 228.000 & 0.000 & 0.078 \\
\hline Signage tips & 326.167 & 0.000 & 0.135 \\
\hline Red Crescent bases & 221.667 & 0.000 & 0.172 \\
\hline Nightly entertainments & 340.667 & 0.000 & 0.096 \\
\hline Monetary and banking services & 231.067 & 0.000 & 0.221 \\
\hline
\end{tabular}

Assessing the effect of satisfaction on future behavioral inclinations of tourists

According to the above hypothesis, the Chi-square test with $99 \%$ confidence confirms the relationship between tourist satisfaction as an independent variable $(\mathrm{X})$ and future behavioral tendencies of tourists (retreat) as the dependent variable $\mathrm{Y}(\mathrm{P}<0.05)$. -value $=$ sig $)$ In order to investigate the intensity of the relationship between the two variables, the Phi coefficient has been used in this hypothesis. This coefficient is the amount (0.221) and the places of prayer with a value (0.216) with a lower degree of severity was explained (Table 12).

Table 13: Measuring the Satisfaction Effect on Future Behavioral Desires of Tourists in Ardebil

\begin{tabular}{|l|l|l|l|l|}
\hline Variables & Chi-Square & Sig. & Phi & Sig. \\
\cline { 1 - 5 } Satisfaction & 72.900 & 0.000 & 0.626 & 0.000 \\
\cline { 1 - 3 } Future behavioral inclinations (retreat) & & & & \\
\hline
\end{tabular}

\section{Conclusion}

According to the information obtained from the survey of tourists entering Ardabil in terms of satisfaction with the quality of tourism services in the city, using the Kano model, it can be stated that among the requirements of satisfaction (basic, motivational, functional) the tourists expressed the most dissatisfaction with the basic requirements with a satisfaction rating of 0.341 and a frustration ratio of -0.661 and a total satisfaction of -0.320 . Among the indicators related to the basic requirements from the tourists' point of view, the used as a symmetric coefficient when both variables are at the $2 * 2$ nominal measurement level (test of the relationship between two variables). Since the coefficient of Phi is used only for tables $2 * 2$, in these tables, the Phi value is equal to the Pearson correlation coefficient. The results of the test also show the strength of the relationship between the two variables at the significant level of 0.000 (Table 13).

historical sites and ancient buildings with a satisfaction index of 407.0 with the most important index and WCs with an inferiority coefficient of -0.704 in terms of creating a firstrate dissatisfaction on the tourists' side. Among the indicators related to the requirements of the operating factors of taxis and public vehicles with a satisfaction index of 0.794 , the most important indicator and services and cultural facilities (concert halls, cinemas, theaters, museums, art galleries and ... ) with a coefficient of -0.703 for the first time, due to the lack of satisfaction. 
According to the results, functional requirements with a satisfaction index of 0.731 are in the first rank, satisfaction coefficients and total satisfaction of -0.607 and 0.124 respectively. regarding the requirements of the fuel service provider with a satisfaction index of 0.777 , the most important indicator is the supply of bread in bakery and food products with a coefficient of -0.524 in terms of creating a first-rate dissatisfaction from tourists. Motivational requirements with satisfaction coefficient of 0.628 and dissatisfaction coefficient of -0.461 were satisfactory in terms of total satisfaction with 0.167 coefficient.

\section{Suggestions}

- The positive image of the destination should be taken care of. Advertising is more effective and less costly than other methods.

- The results show that very few tourists have visited the Ardabil county through the tour. Therefore, the activity of tour operators at this destination should be increased.

- The high percentage of previous trip experience of $26.9 \%$ in returning to the region is suggested to be carefully designed to provide suitable services for travelers and create the grounds for their desired experience and positive image of the destination. Advertising is more effective and less costly than other methods.

- Considering the importance of tourism information centers in increasing the level of tourist satisfaction mentioned in the results of hypothesis number three. The use of catalogs and photographs of the tourist attraction of Ardabil county is recommended.

\section{References}

Bayraktaroğlu, G., \& Özgen, Ö. (2008). Integrating the Kano model, AHP and planning matrix: QFD application in library services. Library Management, 29(4/5), 327-351.

Cengiz, B. (2012). Residents' Perceptions of and Attitudes Toward Sustainable Tourism Planning and Management in Amasra (Turkey). In Landscape Planning. IntechOpen. http://www.intechopen.com. (Access date: 06.06.2016).

Cultural Heritage, Handicrafts and Tourism Organization of Ardabil Province, (2016). http://ardabilchto.ir/0/FA/. (Access date: 06.06.2016).

Gao H.S., \& Xue Q.H. (2016). Research on the development of Hangzhou Mejia dock tea health tourism product system, Journal of Yunnan Agricultural University (SOCIAL SCIENCE), 10(06), 73-77.

Gee, C.Y. (1999). International tourism: a global perspective. Madrid, Spain: World Tourism Organization.

Haque, A., \& Khan, A. H. (2013, February). Factors influencing of tourist loyalty: A study on tourist destinations in Malaysia. In Conference: proceedings of 3rd Asia-Pacific business research conference, Kuala Lumpur, Malaysia, 19(1), 25-26.

Karakuş, Y., \& Çoban, S. (2018). Evaluation of Stakeholders' Expectations Towards Congress Tourism by Kano Model: Case of Nevşehir. Anais Brasileiros de Estudos Turísticos-ABET, 8(2), 820.

Lee, C.C., \& Chang, C.P. (2008). Tourism development and economic growth: a closer look at panels. Tourism Management, 29(1), 180-192.

Lin, F. H., Tsai, S. B., Lee, Y. C., Hsiao, C. F., Zhou, J., Wang, J., \& Shang, Z. (2017). Empirical research on Kano's model and customer satisfaction. PloS one, 12(9)

Mendes, J.D.C. Valle, P.O.D. Guerreiro, M.M., \& Silva, J.A. (2010). The tourist experience: Exploring the relationship between tourist satisfaction and destination loyalty. Turizam: međunarodni znanstveno-stručni časopis, 58(2), 111-126.

Mikulić, J., \& Prebežac, D. (2011). A critical review of techniques for classifying quality attributes in the Kano model. Managing Service Quality: An International Journal, 21(1), 46-66.

Mikulić, J., \& Prebežac, D. (2016). The Kano model in tourism research: a critical note. Annals of Tourism Research, 61, 25-27.

Nasiri, E., \& Amozadmahdiragi, H. (2014). Investigation of Satisfaction of Citizens on Municipal Service Performance Using the Kano Model Case study; Gorgan 
Municipality.Geography and Urban Planning Regional. 13(1).97-106.

Numanoğlu, E., \& Güçer, E. (2018). Yerel Halk Açısından Yavaş Şehir Akımı Algısı: Perşembe Örneği. Journal of Multidisciplinary Academic Tourism, 3(2), 11-22.

Okello, M. M., \& Yerian, S. (2009). Tourist satisfaction in relation to attractions and implications for conservation in the protected areas of the Northern Circuit, Tanzania. Journal of Sustainable Tourism, 17(5), 605-625.

Oliver Richard, L. (1997). Satisfaction: A behavioral perspective on the consumer. New York ' NY: Irwin-McGraw-Hill.

Ponnam, A., Sahoo, D., \& Balaji, M. (2011). Satisfaction-based segmentation: Application of Kano model in Indian fast food industry. Journal of Targeting, Measurement and Analysis for Marketing, 19(3-4), 195-205.

Sánchez-Rebull, M. V., Rudchenko, V., \& Martín, J. C. (2018). The antecedents and consequences of customer satisfaction in tourism: a systematic literature review. Tourism and hospitality management, 24(1), 151-183.

Truong, T. H., \& Foster, D. (2006). Using HOLSAT to evaluate tourist satisfaction at destinations: The case of Australian holidaymakers in Vietnam. Tourism management, 27(5), 842-855.

Tsai, L.F., Liu, Y.M., Wang, P.W., Shih, M.L., Xie, X,M., \& Shaw, J.C.H. (2011). Application of Kano Model to Discuss Tourist Demands on Service Quality in Recreational Travel, IJCSNS International Journal of Computer Science and Network Security. 11(3), 249-250.

Vassiliadis, C. A. (2008). Destination product characteristics as useful predictors for repeat visiting and recommendation segmentation variables in tourism: a CHAID exhaustive analysis. International Journal of Tourism Research, 10(5), 439-452.

WTO. (2007). A practical guide to tourism destination management. https://www.scottsdaledmc.com/. (Access date: 06.06.2016)

WTTC:World Travel \& Tourism Council (2013). wttc.org. (Access date: 06.06.2016).

Wu,Y. (2017). Model Research on the Factors Affecting Tourist Satisfaction of Wellness Tourism Products Based on IPA Model, Revista de la Facultad de Ingeniería U.C.V., 32(15), 617-624.

Zangi Abadi, A., Mohammadi, J., \& Zinkabash, D. (2006). Internal Market Analysis of Isfahan City. Journal of Geography and Development, 4( 8), 156-131.
Zeinali, B., Jafarpour, M., Hessam, A., Shojaeivand, B., \& Zolghadr, H. (2014). Tourists' Satisfaction with and Loyalty to Shopping Experience: A SocioDemograhic Analysis,International Journal of Academic Research in Business and Social Sciences, 4( 6),67-84.

Zobnina, M., \& Rozhkov, A. (2018). "Listening to the voice of the customer in the hospitality industry: Kano model application", Worldwide Hospitality and Tourism Themes, 10(4), 436-448. 